\title{
A clue for familial mitochondrial disorder
}

\section{Discovering a vintage painting}

Janice C. Wong, MD, Laura A. Foster, MD, and Reza Sadjadi, MD

Neurology ${ }^{\circledR}$ 2018;90:294-295. doi:10.1212/WNL.0000000000004933

Figure A vintage painting of the patient's maternal great-grandfather

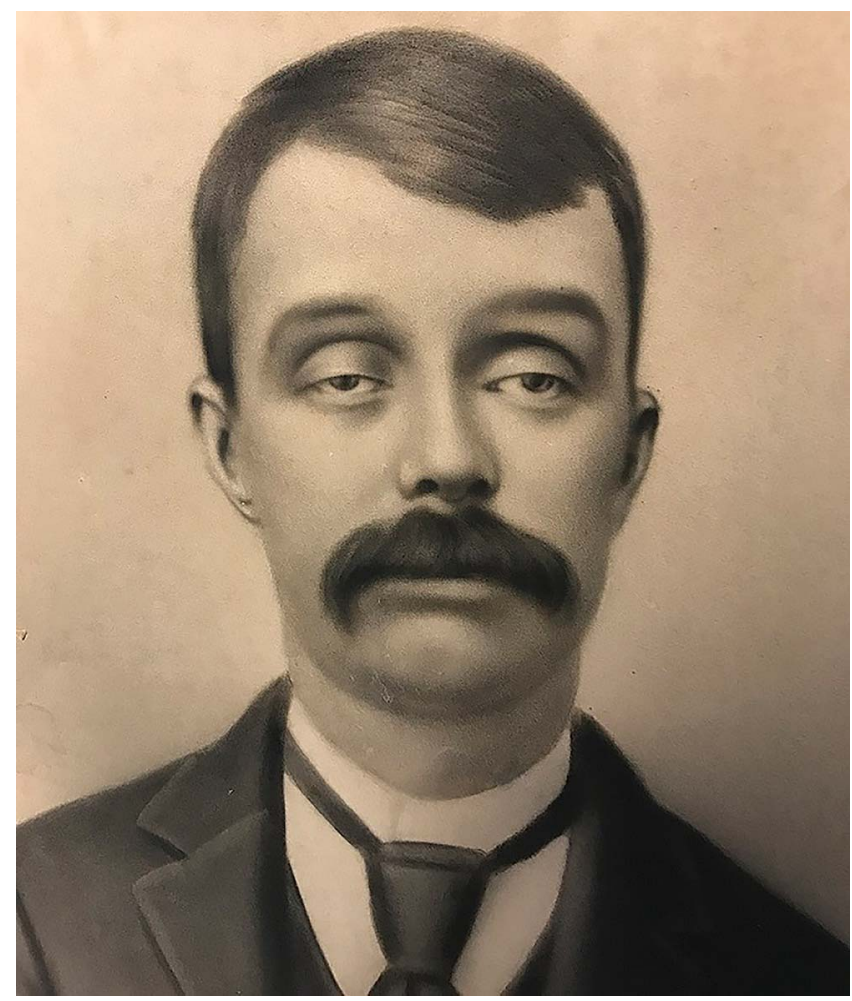

While there are many examples of such strong family history, the painter highlighted astonishing details of severe ptosis, disconjugate gaze, and facial weakness, similar to the patient's presentation. Reprinted with permission of the family.

A 73-year-old man presented with decades of slowly progressive bilateral ptosis and hearing loss. He also had peripheral polyneuropathy, intermittent binocular diplopia, and mild dysphagia and dysarthria. His mother and maternal grandmother had similar symptoms. He later discovered a vintage painting of his maternal great-grandfather (figure), which showed marked ptosis, disconjugate gaze, and facial weakness. Autosomal and maternal mitochondrial genome sequencing from blood revealed likely pathogenic heterozygous mutations at C10ORF2: c1366C > G (p.Leu456Val). The patient was diagnosed with autosomal dominant progressive external ophthalmoplegia, which can be associated with missense mutation of the C10orf2 gene encoding mitochondrial DNA helicase. ${ }^{1}$

\section{Author contributions}

Janice C. Wong: interpretation of data, writing of manuscript, editing of manuscript for critical content. Laura A. Foster: interpretation of data, editing of manuscript for critical content. Reza 
Sadjadi: conception of study, interpretation of data, writing of manuscript, editing of manuscript for critical content, patient follow-up.

\section{Study funding}

No targeted funding reported.

\section{Disclosure}

The authors report no disclosures relevant to the manuscript. Go to Neurology.org/N for full disclosures.

\section{Reference}

1. Hong D, Bi H, Yao S, Wang Z, Yuan Y. Clinical phenotype of autosomal dominant progressive external ophthalmoplegia in a family with a novel mutation in the C10orf2 gene. Muscle Nerve 2010;41:92-99.

\section{Get 10 AAN Practice Management Webinars for Less than \$19 Each}

The AAN is dedicated to helping neurologists improve their practices and delivery of quality care to their patients. The AAN's Practice Management Webinars provide the valuable insights and tools you need to navigate through the ever-changing health care landscape-and receive year-end CME credits!

Purchase webinars individually for $\$ 99$ each, or subscribe to the complete series of 2018 webinars for only $\$ 189-$ that's less than $\$ 19$ per webinar! See the list of webinars and subscribe at AAN.com/view/pmw18.

\section{Sign Up for the AAN's Axon Registry}

The AAN encourages its US members in small group and solo practices to show their interest in participating in the Axon Registry $^{\circledR}$ by signing up today.

Use the Axon Registry to:

- Simplify reporting requirements under MACRA's Quality Payment Program and avoid penalties while reducing your administrative burden

- Meet your MOC Part IV requirements

- Choose from 22 AAN neurology-specific quality measures that fit your practice

- Use data to understand your practice and identify where improvements can be made to patient care

- Demonstrate your value to payers when negotiating reimbursement

- Enjoy multi-year, fee-free access when you sign the agreements and integrate your EHR with the registry

Learn more at AAN.com/view/Axon and send your questions to registry@aan.com. 


\title{
Neurology
}

\author{
A clue for familial mitochondrial disorder: Discovering a vintage painting \\ Janice C. Wong, Laura A. Foster and Reza Sadjadi \\ Neurology 2018;90;294-295 \\ DOI 10.1212/WNL.0000000000004933
}

This information is current as of February 5, 2018

\section{Updated Information \& Services}

References

Subspecialty Collections

Permissions \& Licensing

Reprints including high resolution figures, can be found at: http://n.neurology.org/content/90/6/294.full

This article cites 1 articles, 0 of which you can access for free at: http://n.neurology.org/content/90/6/294.full\#ref-list-1

This article, along with others on similar topics, appears in the following collection(s):

Eyelids

http://n.neurology.org/cgi/collection/eyelids

Mitochondrial disorders

http://n.neurology.org/cgi/collection/mitochondrial_disorders

Information about reproducing this article in parts (figures,tables) or in its entirety can be found online at:

http://www.neurology.org/about/about_the_journal\#permissions

Information about ordering reprints can be found online:

http://n.neurology.org/subscribers/advertise

Neurology ${ }^{\circledR}$ is the official journal of the American Academy of Neurology. Published continuously since 1951, it is now a weekly with 48 issues per year. Copyright (O) 2018 American Academy of Neurology. All rights reserved. Print ISSN: 0028-3878. Online ISSN: 1526-632X.

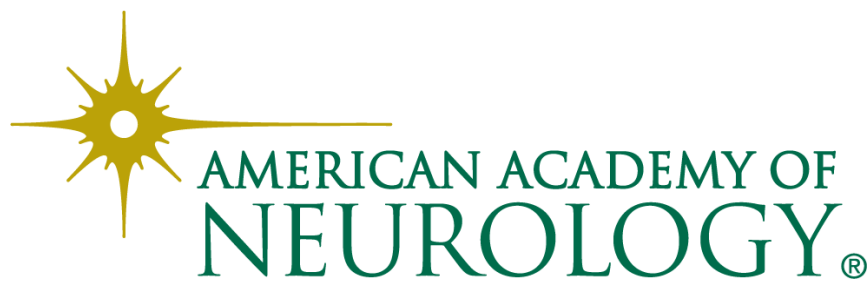

